\title{
Mondo Macabro as Trashy/Cult Film Archive:The Case of Classic Indonesian Exploitation Cinema
}

\author{
Ekky Imanjaya
}

Film archiving and local exploitation films, let alone the trashy film archive, are marginal in the discourses of film journalism, scholarship, policies, and criticism in Indonesia (Imanjaya, 2009c; Imanjaya, 2012a; Imanjaya, 2014). However, this paper will demonstrate the importance of Indonesian exploitation cinema, alternative film archives, and exploitation film preservation. It will focus on the output of Mondo Macabro, a transnational DVD label that consistently preserves world trashy films, including Indonesian films produced from the 1970 s to the 1990 s. By focusing on its DVD paratexts, that is, its DVD covers, special features, and online promotional materials, and applying the Chaperone archiving model also applied by Criterion Collection, this paper will also argue that Mondo Macabro gives trashy or cult films a new lease on life, and more importantly, treats them as collector's items.

Keywords: film archive, Indonesian cinema, exploitation cinema, Chaperone archiving model, digital distribution

Film archiving and local exploitation films, as well as the archiving of exploitation and B-grade films, are marginal in the discourses of film journalism, scholarship, policies, and criticism in Indonesia (Imanjaya, 2009c; Imanjaya, 2012a; Imanjaya, 2014). However, in this paper, I will demonstrate that exploitation movies, exploitation film preservation, and alternative film archiving are important.

I argue that Mondo Macabro (MM) has acted as an archive institution for Indonesia's classic exploitation films, that is, films with gruesome and sensual scenes, which have been overlooked by the Indonesian government and cultural elites. MM, a transnational DVD label that consistently preserves world exploitation films, including Indonesian films from the 1970s to the 1990s, not only commercially recirculated the films in the 2000s but also gave them a new lease on life, introducing them to a new global audience by restoring them and reworking their paratexts in order to chaperone them by explaining their importance to the public. Here, I analyze the function of MM as a trashy/cult film archive and take classic Indonesian exploitation films originally produced between 1979 and 1995 as examples for analysis. 
MM is one of few transnational distributors who legally redistribute Indonesian exploitation films from the New Order era, which is from 1966 to 1998 (Barker, 2014; Imanjaya, 2009c; Imanjaya, 2014; Imanjaya, 2016). As shown in Table 1, the label redistributed H. Tjut Djalil's Lady Terminator (Soraya \& Djalil, 1989) and six other Indonesian exploitation films, among other global cult movies in the 2000s, for the international market.

Table 1: Indonesian exploitation films recirculated by Mondo Macabro (modified from Barker, 2014). ${ }^{1}$

\begin{tabular}{|c|c|c|c|c|c|c|}
\hline No & $\begin{array}{c}\text { Year of } \\
\text { Production }\end{array}$ & $\begin{array}{c}\text { International } \\
\text { Title }\end{array}$ & $\begin{array}{c}\text { Indonesian } \\
\text { Title }\end{array}$ & $\begin{array}{c}\text { Production } \\
\text { Company }\end{array}$ & Director & $\begin{array}{l}\text { Date of } \\
\text { recirculation }\end{array}$ \\
\hline 1 & 1989 & $\begin{array}{c}\text { Lady } \\
\text { Terminator }\end{array}$ & $\begin{array}{c}\text { Pembalasan } \\
\text { Ratu Laut } \\
\text { Selatan }\end{array}$ & $\begin{array}{c}\text { Soraya } \\
\text { Intercine }\end{array}$ & H.Tjut Djalil & 28 Sep 2004 \\
\hline 2 & 1992 & $\begin{array}{l}\text { Dangerous } \\
\text { Seductress }\end{array}$ & $\begin{array}{c}\text { Bercinta } \\
\text { Dengan } \\
\text { Maut }\end{array}$ & $\begin{array}{c}\text { LA 20th } \\
\text { Century } \\
\text { Productions, } \\
\text { Soraya } \\
\text { Intercine }\end{array}$ & $\begin{array}{l}\text { John Miller, } \\
\text { H.Tjut Djalil }\end{array}$ & 16 Nov 2004 \\
\hline 3 & 1987 & $\begin{array}{c}\text { Virgins from } \\
\text { Hell }\end{array}$ & $\begin{array}{l}\text { Perawan } \\
\text { di Sarang } \\
\text { Sindikat }\end{array}$ & Rapi Films & $\begin{array}{c}\text { Ackyl } \\
\text { Anwari, } \\
\text { Fred Wardy } \\
\text { Pilliang }\end{array}$ & 31 Jan 2006 \\
\hline 4 & 1981 & Mystics in Bali & $\begin{array}{c}\text { Mistik } \\
\text { (Punahnya } \\
\text { Rahasia } \\
\text { Ilmu Iblis } \\
\text { Leak) }\end{array}$ & $\begin{array}{c}\text { Pusat } \\
\text { Perusahaan } \\
\text { Film, Video } \\
\text { Tape Corp. } \\
\text { (Sydney) }\end{array}$ & H.Tjut Djalil & 2 Oct 2007 \\
\hline 5 & 1981 & The Warrior & $\begin{array}{c}\text { Jaka } \\
\text { Sembung } \\
\text { Sang } \\
\text { Penakluk }\end{array}$ & Rapi Films & $\begin{array}{c}\text { Sisworo } \\
\text { Gautama } \\
\text { Putra }\end{array}$ & 18 Nov 2008 \\
\hline 6 & 1984 & $\begin{array}{c}\text { The Devil's } \\
\text { Sword }\end{array}$ & Golok Setan & Rapi Films & $\begin{array}{l}\text { Ratno } \\
\text { Timoer }\end{array}$ & $\begin{array}{c}27 \text { June } \\
2006\end{array}$ \\
\hline 7 & 1979 & $\begin{array}{c}\text { Queen of } \\
\text { Black Magic }\end{array}$ & $\begin{array}{c}\text { Ratu IImu } \\
\text { Hitam }\end{array}$ & Rapi Films & Liliek Sudjio & $\begin{array}{c}27 \text { May } \\
2008\end{array}$ \\
\hline
\end{tabular}

Although there are about 46 titles in circulation redistributed by several transnational distributors, only a few films have been recirculated legally, and only by two international DVD labels. Seven titles were recirculated by MM and four titles by Troma Team. Between these two legal distributors, only MM carried out restorations. Other companies such as VideoAsia, Brentwood Home Video, and Maia did commercial bootlegging or illegal copying, with low quality images and sound (Imanjaya, 2016).

Unlike most transnational distributors, MM approaches the films as if it were hidden treasures, which is similar to the approach of Criterion Collection. As a cult cinema distributor who markets its product to global cult fans, MM reworks are meant to rebrand and repurpose the movies. As a result, its films can be accessed publicly and are still in the international DVD circuit, whereas the other Indonesian films from the same era are domestically and globally more difficult to access in high quality. 
In this paper, I will investigate the extent to which we can consider MM as an archival institution for trashy or cult films. I also will interrogate how the distributor's attitude towards the films, particularly the application of the Chaperone archiving model, influences the ways MM rework the films and later determine global fans' consumption and critical reception. I will focus on the reworks done by MM, particularly the images and text from DVD covers and special features, including interviews, short documentaries, texts on the cultural contexts of the films and the filmmakers, as well as other promotional materials on their official website and blog. To get a better understanding on the case I am analyzing, I will elaborate upon four key areas: definition of exploitation/trashy/cult movies, discourses on online film circulation, theories of film archive, particularly Chaperone theory, and history of film archives in Indonesia.

\section{Cult/Exploitation/Trashy Films and the Indonesian Case}

A cult film has been defined by Ernest Mathijs and Xavier Mendik (2007) as

[A] film with an active and lively communal following. Highly committed and rebellious in its appreciation, its audience regularly finds itself at odds with the prevailing cultural mores, displaying a preference for strange topics and allegorical themes that rub against cultural sensitivities and resist dominant politics. (p. 11)

Cult followers are essential to making a movie reach cult status. They are loyalists of the film, watching and celebrating it repeatedly. Commonly, they have "different tastes of cinema" (Mathijs \& Mendik, 2007, p. 18). Some of the characteristics of cult movies are "badness" or poor cinematic achievement; either generic specificity or sometimes the mixing of genres; exposure or defiance of a genre's conventions; and satiric or hyperbolic exaggeration of generic codes, nostalgia, and gore (Mathijs \& Mendik, 2007).

On exploitation cinema, Mathijs and Sexton (2011) wrote: "The films often dealt with forbidden topics, such as sex, vice, drugs, nudity, and anything considered to be in 'bad taste' and commonly low-budget films" (p. 147). Herschel Gordon Luwis defined it as a film practice "in which the elements of plot and acting are subordinate to elements that can be promoted". (as cited in Watson, 1997, p. 78). The marketing strategies are important, as Eric Schaefer (1999) illustrated when he defined exploitation as a mode of film promotion or advertising, particularly posters, trailers, and newspapers ads. In short, exploitation cinema's characteristics are "ethically dubious, industrially marginal, and aesthetically bankrupt" (p. 17).

In the Indonesian context, the terms "exploitation films" and "cult cinema" had not been familiar to local film critics, scholars, and journalists, 
until the films were globally rediscovered massively in early 2000s. However, film critic Salim Said (1991) had been using some similar terms, namely, "slapdash films," "poor quality films," and "trashy films" (p. 89), which could be interchangeable. Based on the descriptions of all these terms, I argue that they are all about the same kind of films. And in this paper, I adopt Said's term "trashy films," one of the terms associated with exploitation films that has been applied by one of Indonesia's cultural elites.

In Indonesia, particularly during the New Order era, the time these films were originally produced and distributed, trashy films were overlooked and heavily criticized by the government and cultural elites, as well as by film critics and scholars (Imanjaya 2016). The New Order government and Indonesian cultural elites always tried to exclude local exploitation films from the discourses of the concept of a national cinema and national film cultures, for they believed films should represent "true" Indonesian cultures, depict "the real faces of Indonesia," and contain educational and cultural issues (They were known as Film Kultural Edukatif, particularly in the 1980s and 1990s.) (Barker 2011, Jufry, Baharuddin, \& Pasaribu, 1992; Said, 1991; ). On the other hand, the films were not verily being marginalized by the audiences because they were watched by mainstream spectators, and some of them became box office hits (Imanjaya, 2016). And paradoxically, starting in the early 2000s, the films were rediscovered and recirculated overseas, and global fans did consider the films as representations of Indonesia and labeled these films "Crazy Indonesia" (Imanjaya, 2016).

\section{Discourses on Cult Digital Distribution}

Textual afterlife of the films can be extended with the home video format after their original theatrical releases and attempts at repurposing is one of the keys to "a different social and historical milieu, as well as different context of reception" (Klinger, 2006, p. 8). As demonstrated by Alan Robert Brookey and Robert Welterfelhaus (2002), the DVD format is an effective way to repackage movies in the context of home viewing and drive the audience to get a particular viewing experience and reception by using extra-texts such as interactional features (p. 21). Through interactive such as "behind the scenes," commentaries, and storyboards, the audience at home can see "what they want to choose, when and in what order" (pp. 22-23).

According to Ramon Lobato (2012), "the act of distribution also materially shapes the text itself, adding another layer of meaning to the viewing experience" (p. 18). At the same time, it can "shape public taste as well as reflect it, creating a feedback loop between distribution and demand" (p. 18). It is the role of distributors to both frame the film and feed fans' tastes through the reworking of filmic extra-texts through re-dubbing, re-titling 
and re-editing, which not only contextualizes these works but also makes them more suitable to the global fans' needs and expectations, leading to the cult status of the films. Hence, the role of the distributors in selecting and disseminating the films for global distribution is very important in facilitating the decontextualization and subsequent reconceptualization of the films (Lobato, 2012).

It is important to note that most transnational distributors, including Mondo Macabro, deliberately market these films as "cult films," a phenomenon described by Mathijs and Sexton (2011) as "meta-cult," as they label their own products using the term "cult movies" to appeal to specific markets (p. 238).

Related to the rework done by transnational distributors, Jay Paul Telotte (1991) suggested that inter-textual materials are important to endorse the presence and survival of cult films (p. 8). Bonus special features, such as extra-texts, including trailers at the beginning, have been common practice in the home video business since the 1980s, especially related to the re-released classic films (Berteluni \& Reich, 2010). Many DVD companies have re-edited, re-subtitled, added documentaries and biographies of the filmmakers and actors, and added commentaries from the filmmakers and critics. Thus, transnational distributors select and remake the promotional materials to both feed and frame global cult fans' tastes, as most of the fans only have access to the films through home videos. The distributors' curatorial process, as their politics of taste, has become important not only in choosing and excluding particular films but, as mentioned by Lobato (2012), also "involves all the typical textual reframings involved in crossborder marketing and numerous textual modifications (retitling, selective [re]dubbing, re-editing removal of culturally specific content) . . . which facilitated the de-contextualization and subsequent reconceptualization of the films" (pp. 197, 199). By implication, this kind of curatorial process frames "how Western audiences interpret and understand Asian cinemas and, by extension, Asian cultures" (Lobato \& Ryans, 2011 p. 198). Therefore, the role of distributors in selecting and discriminating the films for international markets and recirculating them with some reworkings in DVD cult circuits is very important in shaping the public's taste (pp. 16-18). Additionally, extra-textual matters are important for the cult-ness of a text.

It is important to note that in this paper, I consider DVD paratexts as added value. As Paul McDonald (2007) has discussed, if the DVD distributors have the film rights, they can use extra materials from previously remaining resources or make new documentaries and interviews, produced by themselves or external sources (p. 67). McDonald, when discussing The Criterion Collection, stated that extra-texts not only give added value but 
also deepen viewer understanding of the content and even position the audience closer to the viewing experience in movie theaters. Furthermore, commenting on Criterion, Berteluni and Reich (2010) wrote:

Since the late 1990s, most DVD editions of classic, critically rediscovered, and new films have made the audio commentary a key component of an ever-growing menu of special features-including entire director's cuts, deleted scenes, making-of documentaries, exclusive or vintage interviews with the film's makers or celebrated critics, video essays, professional biographies, and photographic essays. (p. 104)

Another important concept for this paper is the theory of "fans as collectors." Barbara Klinger (2006) differentiated between two categories of collectors: The first is the high-end collectors, who have the budget to purchase high-quality DVDs and home video instruments; the second is the low-end fans, who do not focus on those elements and prefer obscure titles, even though the images are of low quality (pp. 63-64). The buyers of Mondo Macabro belong to the first category.

Lastly, for this paper, "digital distribution" would refer to reworks by $\mathrm{MM}$ and the idea of MM reworks as part of the Chaperone model strategy of archiving. As discussed by Giovanna Fossati (2009), a restored film can have a new life, increasing the visibility of archival films in the public sphere. So film archives have also started new forms of distribution alongside traditional theatrical distribution, such as DVD, TV rights, and film festivals. One of the distribution models is the Chaperone model. The archival films in this case are brought to the public, with the archives acting as a chaperone to "show the way and, at the same time, protect the films and their content" (p. 96). The archivists do not only act to restore the films but also become curators, explaining the significance of the films to the public. Before analyzing how the Chaperone model applies in MM's case, I will briefly discuss the history of film archiving in Indonesia to demonstrate the distributor's importance as a trashy film archivist.

\section{Film Archive in Indonesia}

It is commonly known that film archive institutions are being neglected in Indonesia. Sinematek Indonesia (SI), the main and biggest film archive in the country, until recently lacked funding for the maintenance of its collection, despite its successful restoration of Lewat Djam Malam [After Curfew] (Ismail/Ismail \& Malik, 1954) in 2012, with the help of the National Museum of Singapore, World Cinema Fund, Konfiden, and Kineforum 
(Wenjie, 2012); and Tiga Dara [Three Sisters] (Ismail \& Ismail, 1956) in 2016, funded privately by SA Films ("Restored Classic Tiga Dara," 2016). In fact, most people do not understand the importance of a film archive and hence do not support film restoration. For example, when Misbach Yusa Biran, the founder of SI, was still only planning to establish SI in 1970, he visited Tan Tjoei Hock, the only person alive who had experienced and witnessed filmmaking in the Japanese era. Hock questioned Biran's good intentions, asking "Why do you do this? It is useless and an unimportant job to do" (Imanjaya, 2012a). As a result of this kind of attitude, there are few proper restoration projects undertaken in Indonesia (Imanjaya, 2011).

The biggest nationwide attention given to a film restoration was to Lewat Djam Malam (Imanjaya, 2012a; Pasaribu, 2012a; Pasaribu, 2012b). For the first time in Indonesian history, restoration of a classical film became a national issue. It happened during February and May 2012, when Lewat Djam Malam became the first Indonesian film that underwent the fullrestoration process and was screened at the 2012 Cannes Film Festival as the opening film of Cannes Classic Program, on May 17 (Cannes Classics, 2012; Sekarjati, 2012a; Sekarjati, 2012b). On its national premiere in Jakarta on June 18, there was a short video speech by Martin Scorsese, the chairperson of the World Cinema Foundation who also represented one of the institutions involved in the project. The film was screened in a national commercial cinema chain for over a month. Interestingly, no significant contribution came from the Indonesian government (Wenjie, 2012).

Lewat Djam Malam was not the first attempt at film restoration in Indonesian cinema. For example, between 1982 and 1991, David Hanan completed four film preservation projects-not full restoration ones but only digitization-that were funded jointly by the Monash University Library and the National Library of Australia Film Studies Collection, with technical advice and other forms of assistance provided by the National Film and Sound Archive of Australia (Hanan, 2018).

Two major Indonesian feature films, shot and originally released on $35 \mathrm{~mm}$ color and cinemascope but surviving only on $16 \mathrm{~mm}$, were preserved by the making of 16 millimeter internegatives and a number of viewing prints. Another major feature film, surviving as only one $35 \mathrm{~mm}$ print, was preserved in the same way. The films are: Si Mamad (Sjumandjaya, 1972), Atheis (Sjumandjaya, 1974), Nji Ronggeng (The Ronggeng Dancer, Alam Surawidjaya, 1969). The internegatives and one print of these films were then sent to Sinematek Indonesia in Jakarta, which holds the originals that were copied during the preservation process. The fourth preservation project was the preservation of a group of short films: Short Film and Animation Works by Gotot Prakosa 1974-1987. These films by Gotot Prakosa are now 
available from Monash Asia Institute between Three Worlds Video (Hanan 2018). (Hanan, 1979; Hanan, 2018).

A year after the release of Nagabonar Jadi Dua [Nagabonar Became Two] (Wiranegara/Abiyoga \& Deddy Mizwar, 2007), Deddy Mizwar also carried out some restorations on the sound and image of the first Nagabonar (Nawawi \& Risjaf, 1987), referring to the process as "remastering." Only ten percent of around 144,000 frames were successfully cleaned up and retouched due to the fungus problems with the original. The dialogues were dubbed mostly by the actors involved in the film. At the end of the film, there were songs called "Melihat dengan Hati" [Seeing with Heart] by Eros Sheila on 7 and Apa Kata Dunia [What will the World Say?] by Melly Goeslaw, sung by Deddy Mizwar, and the sound production was changed into Dolby surround digital. In conclusion, the process changed the original film. ${ }^{2}$ The purpose of this restoration was to commemorate Hari Kebangkitan Nasional (National Resurrection Day), and 49 copies were screened in commercial cinemas and later released on VCD format.

In the 2010s, Director of Sinematek Indonesia Berthy Ibrahim supported Falcon Films to restore ten films starring the popular actorssingers Benyamin Sueb and Rhoma Irama for commercial purposes. ${ }^{3}$ The restoration process, involving mostly scanning and retouching, was carried out in Chennai, India, by GoldenEye. The purpose was purely commercial: Falcon Films has planned to distribute and exhibit through mobile phone, web streaming, and DCDM digital cinema through satellite (B. Ibrahim, personal communication, April 25, 2011). And in 2016, Tiga Dara (Ismail \& Ismail, 1956) was restored and released in commercial movie-theaters, 60 years after its initial circulation (Elyda, 2016). The restoration was funded by SA Films with no assistance from the government and was carried out in L'immagine Ritrovata in Bologna. It is the first Indonesian film to be restored in 4K format ("Restored classic Tiga Dara Set for Cinema Return," 2016).

Pete Tombs (personal communication, May 20, 2012), MM's cofounder, also attempted to carry out restorations for commercial purposes in the 2000s. His company, for instance, bought the rights to Jaka Sembung [The Warrior] (Samtani \& Putra, 1981) and Leak [Mystic in Bali] (Sofyan, Katili, Gunawan \& Tjut TDjalil, 1980) and distributed them internationally. Tombs said that both films have received the digital cleanup process on sound and picture at Ascent Media (based in Hong Kong; recently changed its name to Deluxe) from internegative $35 \mathrm{~mm}$, which he shipped from Indonesia to London (P Tombs, personal communication, May 20, 2012). It is evident that the abovementioned restoration projects received almost no significant contribution, especially financial support, from the Indonesian government, and we can see that some of the projects' purposes 
are commercial. Elsewhere, I highlighted the roles of some institutions and media as alternative film archives for domestic exploitation and B-movies (Imanjaya, 2009b). These include Layar Tancap (traveling cinema shows), cheap VCD and DVD by KaryaMas, and transnational DVD labels such as MM (Imanjaya, 2009c; Imanjaya, 2014), as well as YouTube and some commercial restoration by film distributors (Imanjaya, 2012b). And surely one should also mention online film archives, particularly FilmIndonesia. or.id, which is the online version of Katalog Film Indonesia (Kristanto, 2007), and the Indonesian Film Center (indonesianfilmcenter.com). Without disregarding formal institutions such as SI, Perpustakaan Nasional (National Library), which has the series of websites on prominent cineastes, and Arsip Nasional (National Archive), these alternative bodies, from Falcon Films to VCD labels, preserve the popular films-the ones suitable to the taste of a mainstream audience-by digitizing and re-releasing them as home videos or rebroadcasting them through the local television or mobile phones.

In this paper, I will focus on $\mathrm{MM}$ as the example of an alternative archiving organization. As mentioned earlier, the label considers these films as gems and has carried out their preservations. The most important and biggest difference of the work by MM as compared to other DVD labels, both formal and informal, is its attempt to "restore" the film or, as stated on the website, MM provides "brand new anamorphic HD transfer taken from the negative" ("Mystics in Bali (DVD)", n.d.). This is the selling point of MM's DVDs, and the organization always highlights its archival efforts on the back covers of its DVDs. This distinguishes the label from other distributors working on cult films, and since the audiovisual quality is better, the fans are more satisfied. However, as MM is also a profit-oriented business institution, it needs to repurpose the films to suit its own market. Therefore, MM reworks, that is, decontextualize and recontextualize, the films and label them as "cult movies."

\section{Mondo Macabro, Politics of Archive, and Chaperone Model}

As a commercial DVD company, one of MM's main purposes in film restoration is to sell DVDs. However, Pete Tombs, MM's co-founder, is also a passionate fan and specializes in world cult cinema. He has dedicated himself to the study of this kind of films, even writing the book Mondo Macabro: Weird and Beautiful Cinema around the World and co-directing eight episodes of a documentary on this topic for Channel 4 (Tombs \& Starke, 2004; Tombs \& Starke, 2007). Therefore, combining his passion for this kind of films and his marketing savvy, and believing that there is a niche market for films that are "different," Tombs decided to recirculate world classic exploitation films.

Again, to us in the West, the mythology they explored (South 
Sea Queen, Sundel Bolong etc.) was new and very “exotic." There was also something interesting in seeing western exploitation staples, such as the women in prison movie or the monster movie, being filtered through Indonesian eyes. Finally, I suppose for us there was a feeling that things like supernatural horror and black magic were maybe taken a bit more seriously by audiences in Indonesia than they were in the West, for cultural/historical reasons, so the films weren't so self-conscious or "camp" as UK or US productions. (Imanjaya, 2009c, p. 148)

As I mentioned earlier, the most significant modification of the reworks by $\mathrm{MM}$ is its effort to "restore" the movies, and it always underlines these attempts within the promotional materials. Lady Terminator's (Tjut Djalil, 1989) back cover, for example, states: "Previously released in a cut, full-screen version, this DVD restores the film to its original length and is presented in a digitally restored format, enhanced for widescreen TV," whereas on The Warrior's (Sisworo Gautama Putra, 1981) back cover, what is written is "The film is fully remastered and completely uncut." As mentioned earlier, too, the films have undergone the restoration process on sound and picture. In an interview in 2009, Tombs said that while writing his book, he had already contacted some filmmakers for his own research projects and had started making the documentary series under the same title for Channel 4 (P. Tombs, personal communication, May 20, 2012). And, naturally, after he established a good network within Indonesian filmmakers, he began to set up a curatorial team to plan for re-releasing the films, including legally buying the rights from the owners and transferring and cleaning up the materials from $35 \mathrm{~mm}$ to digital forms in Hong Kong and Thailand, and later on in England for better results. Tombs admitted that the hardest part was to find out who owned the distribution rights and whether the owners still had the materials or not. The other crucial thing was the costly budget for the transfer and cleanup process (Imanjaya, 2009a; Imanjaya, 2009b; Imanjaya, 2009c).

As a formal distributor, $\mathrm{MM}$ can restore the films and exploit the materials such as interviews and documentaries that can be put as extratexts in the DVD special features. I argue that both the restoration effort and the distributor's treatments are attempts to frame, as well as preserve, valuable materials, and lead to the "Chaperone model" of archiving, as Fossati (2009) puts. I argue that MM already applied the Chaperone model of archiving by providing rich materials on trivial information about each film, as well as treating the films as rare collectible items and promoting its efforts as added value in order to attract the fans' attention. Another 
important thing was that MM already paved the way for these exploitation films to gain proper, decent, appreciative public access, and further framed and contextualized the films by showing the importance of their existence in the global context.

\section{Meta-Cult Strategy and the Works of Mondo Macabro}

MM's efforts, however, are aimed at a specific market, namely global fans with a taste for classic world cult movies, as the label also positions itself as the global cult cinema distributor. Therefore, the company's second strategy is to rebrand the films as cult movies. As discussed earlier, Mathijs and Sexton (2011) called this kind of attempt the meta-cult strategy. Intentionally, MM uses the word "cult" as a tool to promote the films and fascinate the spectators with certain tastes (pp. 235, 238). This strategy includes online promotion on MM's official websites (http://www.mondomacabrodvd. com/ and https://mondomacabro.bigcartel.com/); redubbing; and putting endorsements and bombastic statements on the front and back covers of its DVDs.

Regarding the official websites, I argue that MM DVDs enact metacult marketing strategies (Mathijs \& Sexton 2011, pp. 235, 238) by driving prospective buyers to the world of cult cinema. The websites evidence some attempts to associate the films with cult status. MM frames the films as cult movies through online promotion by highlighting the strangeness and exotic elements of the films and using popular terms in Western cult and exploitation cinema traditions, including grindhouse cinema. For example, The Warrior (Samtani \& Putra, 1981) is described as "packed with jawdropping action scenes and astonishing special effects ... the ultimate cult classic, spawning four sequels." Mystics in Bali (Sofyan, Katili, Gunawan \& Djalil, 1981) promotional materials say the film is "the holy grail of Asian cult cinema!" Dangerous Seductress (Soraya \& Djalil, 1992) is an amazing combination of bloodsucking, black magic and killer babes-a real midnight movie classic: "Wild and wicked, as only Asian movies can be."

MM highlights the weirdness of the films as well as the restoration work, as seen, for example, in the Mystics in Bali (Sofyan, Katili, Gunawan \& Djalil, 1981) promote on:

This is the film that introduced a new kind of monster to the world's cinema screens. A sensation on its initial release in Asia, Mystics in Bali was deemed too bizarre and shocking to be screened in the west. Until now.... This is the first time the film has been released in the US and is completely uncut and digitally remastered from the rare original negative .... 
Plans that culminate in one of the most bizarre and shocking scenes in all horror cinema .... (para. 3)

Furthermore, the promotional material for Lady Terminator (Soraya \& Djalil, 1989) not only mentions the film as "one of the key cult movies of the 80 s" but even relates the film with grindhouse cinema in 42nd Street, New York: "Even the jaded patrons of 42nd street were shocked to see how the lustful Lady $\mathrm{T}$ dispatched her victims . ..!" The statement can be read on both their websites and on the Lady Terminator back cover.

MM effects the practice of meta-cult marketing as indicated by Mathijs \& Sexton (2011), also through its DVD covers. Generally, every promotional statement in MM's official websites is automatically put on the back cover of the DVDs, with a similar purpose: to make it more suited to the taste global cult fans. Additionally, MM puts a strong, one-line statement on the back or front cover, such as "Sex, Savagery, and Mystical Martial Arts, An Astounding Voyage into the Unknown" ("Devil's Sword (DVD)". Again, weirdness and the bizarre elements are emphasized, using popular cult terms.

The (re)dubbing element is also a meta-cult strategy. Although the Indonesian producers already dubbed the films into English for the international market, MMhasredubbed thefilmsto makeit moreconcomitant to their core market. Some clear examples of reconceptualization of the films can be seen in The Warrior (Samtani \& Putra, 1981), where Western figures such as Caligula and Mata Hari are mentioned to describe the characters. Those two names cannot be found in the original version. The global cult fans are most probably familiar with the two names, but I argue that many of the Indonesian audiences do not recognize the names, especially those working-class and lower-class viewers who watch the films in suburban and rural areas.

The movie trailer is also another significant meta-cult element. In its trailers, MM always chooses the exotic and the otherness of the films. In addition, in its trailers ("Mondo Macabro Promo", 2007) MM always treats Indonesian films the same way as other world cult films (Imanjaya, 2009c, 148), ${ }^{5}$ both in the promotional trailers in the bonus features or other channels, and its official websites. This means that as part of metacult marketing strategy, MM validates the cult-ness of the exploitation films from Indonesia and frames the perception of global fans so that the films are seen as part of and equal to world cult cinema.

The last significant MM's meta-cult strategy is their DVD's Bonus Special Features. Cult framings are enhanced by the rich data of the extra-text in the DVD's special features. For example, in The Warrior DVD, we can find an essay by Pete Tombs, cast biographies, and interviews with producer Gope 
T. Samtani and screenwriter Imam Tantowi (Tombs \& Starke, 2007). Devil's Sword includes an exclusive interview with the film's star Barry Prima and an essay titled Heavenly Swords: A History of Magical Swords by Pete Tombs ("The Devil's Sword", n.d.). Some other bonus features include a half-hour documentary on Indonesian exploitation films, alternate scenes, extensive background information, and stills galleries.

The interviews and documentaries were taken from one of the episodes on global cult films for Channel 4. The project was carried out in 2001, where MM's co-founders, Tombs and Andrew Starke, were teamed up for a documentary series titled Mondo Macabro for Channel 4, based on the book with the same title. The TV series has eight episodes, ${ }^{6}$ including Fantasy Films from Indonesia (aired in 2002), which later became bonus special features for the DVDs (Tombs \& Starke, 2002/2004; Tombs \& Starke, 2007).

Another example is the Dangerous Seductress (Soraya \& Djalil, 1992) bonus features, where we can find a featurette on SFX maestro Steve Prouty, an interview with the director, and an SFX commentary from Steve Prouty. For the Queen of Black Magic DVD (Kasdani \& Sudjio, 1981), a short documentary titled Indonesian Light \& Magic: Behind the Scenes with FX guru El Badrun [The Queen of Black Magic] is included. All reworks have been possible as $\mathrm{MM}$ is a formal distributor and therefore is able to restore the films and exploit materials, such as interviews and documentaries that can be provided as extra-texts in the DVD special features. Both the restoration effort and the distributor's treatments are an attempt to frame, as well as preserve, valuable materials, and lead to a Chaperone model of archiving.

\section{Fans' Critical Responses}

The reworks stood out among other brands and were praised by global fans. For example, one of the bloggers, Den Boer (2006), compared VideoAsia with MM:

If you look closely during the opening credits you can see that some of titles are missing off frame. Also some compositions during the film feel too cramped and early on in the film there are noticeable tape rolls. Both of these films have been sourced from VHS masters so don't expect them to look as spectacular as the excellent Mondo Macabro release for Virgins from Hell . . Jungle Virgin Force and Hell Hole are two action packed and entertaining films that deserve a better release then this. Hopefully some company like Mondo Macabro will pick these up and give them the 
tender loving care they desire. Overall Tales of Voodoo Volume 1 is a totally worthless release despite its cheap retail price. It is one of those instances in which you get what you pay for which is two solid films that are marred by crappy transfers that fail to take full advantage of DVD format.

In a review of Virgins from Hell in an online fanzine Cinema Strikes Back, the reviewer praised the wide screen presentation-he described it as "crisp 2.35:1 remastered anamorphic widescreen"-and the essay on women-in-prison films by Pete Tombs, as well as the original documentary on Indonesian exploitation films (Austin, 2006b). The same appreciation comes from Elijah Drenner (2007) who writes for Film Fanaddict. He underlined the clean-up process as producing "a sharp picture, with bright colors and bold contrasts in video quality" (Drenner 2007). Michael Den Boer also discussed the ratio when reviewing The Warrior (Boer, 2008), stating that:

[T] he film opens with a disclaimer from Mondo Macabro about the quality of the transfer having some minor flaws due to the source materials that exits for this film. [But] overall this is another first rate progressive flagged transfer that is on par with Mondo Macabro's other Indonesian DVD releases. This release comes with one audio option a Dolby Digital Stereo English mix. Outside of some minor instances of hiss the audio sound clear and evenly balanced. (Boer, 2008)

The same compliment was also detected in Den Boer's reviews on Mystics in Bali (2007), Devil's Sword (2006a) and Austin's article on The Devil's Sword (2007). Related to bonus features, meanwhile, Drenner (2007) wrote:

Man, oh man. The good folks at Mondo Macabro seem to outdo themselves on a fairly consistent basis, and with VIRGINS FROM HELL, one of the latest from those Purveyors of Perverted-this DVD company can maintain their stranglehold on the world of exotic and weird films from around the world .... If the movie itself wasn't enough to melt your brain, Mondo Macabro has added a bonus disc of trailers from Rappi (sich! EIJ) Films, the bastards responsible for this movie. (Drenner, 2007) 
The reviews above show the satisfaction of the market and therefore underline the success of MM's Chaperone mode of archiving. By highlighting the technical characteristics of the releases, MM has collectors that are closer to Klinger's "high-end" collectors, who prioritize the audio-visual quality and are willing to pay more to get the original package enriched with special features.

\section{Conclusion}

Trashy film archiving, that is, the act of archiving exploitation and B-grade movies, is not a popular term in Indonesia and in film studies in general. Both film archive activities and exploitation movies, let alone film archive focusing on the exploitation films, are not part of the mainstream discourses because most film activists, scholars, and critics do not consider them as significant and important. Nonetheless, trashy film archiving is important, not only because it can revive the films from different generations and era but also because it can highlight both the aesthetic and cultural importance of the films through the special features that contain such information as trivia, short documentaries, interviews, and articles. Through these attempts, trashy film archives, using the Chaperone model of archiving, can challenge the mainstream discourses of film history, film criticism, and film studies that commonly overlook, underestimate, and criticize this kind of the films.

In this paper, I analyzed MM as the best practitioner of the trashy film archive. I argued that MM acted as an archiving institution for underrepresented world exploitation films, particularly the ones from Indonesia. The successful attempts of MM give the films a new life and new audiences and fans from different generations. The films digitally recirculate in DVD circuits after 20-30 years of their initial production and exhibition, longer than most Indonesian films in the same era. MM cleaned up the films and, as a result, gained best audiovisual quality then later fans' satisfaction. The company acted as a chaperone, to "show the way and, at the same time, protect the films and their content" (Fossati, 2009, p. 96), as well as became curators, framing the importance of the films to the public. It used the Chaperone model of archiving by treating the films as collectible items and enriching the special features with trivial information, interviews, and other related audiovisual and written documents. As a result, many global cult fans, particularly the high-end collectors, are satisfied with the reworks as they consider the films as gems.

However, as a common practice, MM has reworked the films to make them more suitable to the tastes of their market, namely, cult fans. It also retitled and redubbed the films. Since the company, as a world cult film 
distributor, tried to make the films more concomitant with the global cult fans and with their own taste with Western cult and exploitation traditions (titles, dubbing, taglines of DVDs), it recontextualized the films from their original cultural contexts and framed them as cult movies. This attempt of repurposing, I argue, is necessary in order for the films to reach "a different social and historical milieu, as well as different context of reception" (Klinger, 2006, p. 8).

By going through all these efforts, MM has been acting as an alternative archive institution particularly as a trashy/cult film archive. Nonetheless, MM has only legally archived seven out of more than 40 titles in Indonesian cinema. Tombs admitted that the hardest part of the process is to find out who owns the distribution rights and whether the owners still has the materials or not. Another crucial factor is the costly budget for the transfer and cleanup process (Imanjaya, 2009a; Imanjaya, 2009c; Imanjaya, 2016). I argue that these are the main reasons why MM does not restore more Indonesian films. Regardless of this limitation, MM has proven to be one of the institutions of the trashy film archive that have successfully given life to these films and have highlighted their importance by providing more context and other added value to the special features for the global fans. 


\section{References}

Austin, D. (2006a, April 9). The devil's sword: Indonesian sword and sorcery epic. Cinema strikes back. Retrieved from https://web.archive.org/web/20120716203436/ http://www.cinemastrikesback. $\mathrm{com} / \mathrm{p}=1307$.

Austin, D (2006b, May 1). Virgins from hell: Dirt bikes, go-go boots, and bazookas from Indonesia. Cinema strikes back. Retrieved from https://archive.is/1pBW9.

Austin, D. (2007, March 14). Golok Setan [The devil's sword]. Retrieved from http://permiashawaiilife. blogspot.co.uk/2007/03/devils-sword-indonesian-sword-and.html.

Barker, T. (2011). A cultural economy of the contemporary Indonesian film industry (Unpublished doctoral thesis). Department of Sociology, National University of Singapore.

Barker, T. (2014, August). Exploiting Indonesia: From Primitives to Outraged Fugitives. Plaridel, 11(2), pp 1-22. Retrieved from http://www.plarideljournal.org/article/exploiting-indonesia-from-primitivesto-outraged-fugitives/.

Berteluni, G., \& Reich, J.(2010). DVD supplements: A commentary on commentaries. Cinema Journal, 49(3), pp 326-336.

Boer, M. (2006, June 21). Devil's sword. Retrieved from http://10kbullets.com/reviews/devils-sword-the/

Boer, M. (2007, September 20). Mystics in Bali. Retrieved from http://10kbullets.com/reviews/m/mysticsin-bali/

Boer, M. (2008, November 17). Warrior, the - 10,000 Bullets. Retrieved from http://10kbullets.com/ reviews/t/warrior-the/.

Brookey, A., \& Welterfelhaus, R. (2002). Hiding eroticism in plain view: The Fight Club DVD as digital closet. Critical Studies in Media Communication, 19(1), 21-43.

Cannes Classics 2012. (2012). Festival du Cannes. Retrieved https://www.festival-cannes.com/en/infoscommuniques/communique/articles/cannes-classics-2012.

Dangerous Seductress (DVD) (n.d.). Retrieved from https://www.amazon.com/Dangerous-SeductressKristin-nin/dp/B00061QIXG/ref=sr_1_1?ie=UTF8\&qid=1542081954\&sr=8-1\&keywords=Dangero us+Seductress

Devil's Sword (DVD) (n.d.). Retrieved from https://www.amazon.com/Devils-Sword-Barry-Prima/dp/ B000FI8MMK/ref=sr_1_1?ie=UTF8\&qid=1542082410\&sr=8-1\&keywords=The+Devil\%27s+Sword.

Drenner, E. (2007, April, 15). Virgins from Hell (1987). Retrieved from https://web.archive.org/ web/20160811042944/http://www.shockingimages.com/modules/smartsection/item. php?itemid=122.

Elyda, C. (2016, 13 August). Restored Tiga Dara wins new generation of fans. The Jakarta Post. Retrieved from http://www.thejakartapost.com/news/2016/08/13/restored-tiga-dara-wins-new-generationfans.html.

Fossati,G.(2009). From grain to pixel:The archival life of film in transition. Amsterdam:Amsterdam University Press.

Hanan, D. (1979). 1979. Short Films and Animation Work by Gotot Prakosa | Monash Asia

Institute. Retrieved from http://artsonline.monash.edu.au/mai/work-by-gotot-prakosa/

Hanan, D (2018). Sinematek Indonesia: Formidable Achievements in film collection and research - But a collection under threat. Plaridel, Vol. 15 No. 1, January-June 2018. Retrieved from http://www. plarideljournal.org/wp-content/uploads/2018/06/2018-01-Hanan.pdf. 
Imanjaya, E. (2009a, March). Pete Tomb penjaga taman film eksploitasi Indonesia. Trax Magazine., 26-

27. Retrieved from http://1.bp.blogspot.com/-sNy8n7sjWFw/UKJQVRUNqil/AAAAAAAAALQ/ NvllZOafaLo/s1600/trax_14.jpg.

Imanjaya, E. (2009b, May 15). Desperately seeking alternative archiving institutions: Exploitation classical Indonesian cinema cases (Paper presented at SEAPAVAA General Assembly and Conference, Bandung).

Imanjaya, E. (2009c, December). The other side of Indonesia: New Order's Indonesian exploitation cinema as cult films. COLLOQU text theory critique, 18. Retrieved from http://colloquy.monash.edu.au/ issue018/iminjaya.pdf.

Imanjaya, E. (2011, June 7). Pak Misbach. Rumah Film. Retrieved from https://web.archive.org/ web/20120115030244/http://new.rumahfilm.org/blog/film-is-not-a-dream/pak-misbah.

Imanjaya, E (2012a, October 16). 35 Tahun Sinematek Indonesia: Misbach Yusa Biran, Museum Kita, dan Media Sosial. Film is not a dream, life is. Retrieved from http://web.andreaskrisna.com/sinematekindonesia-misbach-yusa-biran-museum-kita-dan-media-sosial-331.

Imanjaya, E (2012b). Semua terekam tak pernah mati (?): Media baru sebagai museum. In Wardhani, Diah and Afdal Makkuraga Putra (Eds.), The Reposition of communication in the dynamic convergence: Reposisi komunikasi dalam dinamika konvergensi. Retrieved from http://fikom.mercubuana.ac.id/ wp-content/uploads/2015/07/SemuaTerekamTakPernahMati_Ekkylmanjaya.pdf.

Imanjaya, E. (2014). An introduction: The significance of Indonesian cult, exploitation, and B movies. Plaridel Vol. 11 No. 2, August 2014. http://plarideljournal.org/article/significance-indonesian-cultexploitation-and-b-movies Accessed 10 November 2018.

Imanjaya, E. (2016). The cultural traffic of classic Indonesian exploitation cinema (Unpublished PhD thesis). School of Arts, Media, and American Studies, University of East Anglia.

Ismail, U., \& Malik, D. (Producers), \& Ismal, U. (Director). (1954), Lewat djam malam [After Curfew] [Motion picture]. Jakarta: Perfini \& Persari.

Ismail, U. (Producer), \& Ismail, U. (Director). (1956), Tiga dara [Three sisters] [Motion Picture]: Jakarta: Perfini.

Jufry, M., \& Burhanuddin, \& Pasaribu, W. (Eds.). (1992). Indonesian film panorama. Jakarta: Permanent Committee of the Indonesian Film Festival.

Klinger. B. (2006). Beyond the multiplex: Cinema, new technologies, and the home. Berkeley \& Los Angeles: University of California Press.

Kristanto, J. (2007). Katalog film Indonesia 1926-2007. Jakarta: Penerbit Nalar.

Lady Terminator (DVD) $\quad$ (n.d.). Retrieved from https://www.amazon.com/Lady-TerminatorBarbara-Anne-Constable/dp/B0002VER3S/ref=sr_1_1 ?ie=UTF8\&qid $=1542081761 \&$ sr $=8$ $1 \&$ keywords=lady+terminator.

Lady Terminator. (n.d). Retrieved from http://www.mondomacabrodvd.com/mod108.html Soraya, R (Producer) \& Djalil,T (Director) (1989). Lady Terminator [DVD]. Jakarta: Soraya Intercine.

Lobato, R. (2012). Shadow economies of cinema: Mapping informal film distribution. Basingstoke: Palgrave Macmillan.

Lobato, R., \& Ryan, M. (2011). Rethinking genre studies through distribution analysis:Issues in international horror movie circuits. New Review of Film and Television Studies, 9(2), 188-203.

Mathijs, E., \& Mendik, X. (2007). The cult film reader. Maidenhead: Open University Press. 
Mathijs, E., \& Sexton, J. (2011). Cult cinema: An introduction. Oxford: Wiley-Blackwell.

McDonald, P. (2007). Video and DVD industries. London: BFI.

Mystics in Bali (DVD) (n.d.). Retrieved from https://www.amazon.com/Mystics-Bali-Jalil-Jackson/dp/ B000VNMS6K/ref=sr_1_1?ie=UTF8\&qid=1542083186\&sr=8-1\&keywords=mystics+in+bali.

Mondo Macabro Promo. (2007). Retrieved from https://www.youtube.com/watch?v=4avY9UfnqFY\&t=78s Nawawi, B. (Producer), \& Risjaf, M.T. (Director). (1987). Naga Bonar [VCD]. Jakarta: Prasidi Teta Films.

Pasaribu, A. (2012a, February 19). Restoring film history, one movie at a time. Jakarta Post. Retrieved from http://www.thejakartapost.com/news/2012/02/19/restoring-film-history-one-movie-a-time.html.

Pasaribu, A. (2012b, March 31). Restorasi film Lewat Djam Malam hampir selesai. Film Indonesia. Retrieved from http://filmindonesia.or.id/article/restorasi-film-lewat-djam-malam-hampir-selesai-2.

Punjabi, R. (Producer), \& Putra, S.G. (Director). (1981). Jaka Sembung sang penakluk [The Warrior] [ DVD]. Jakarta: Rapi Film.

Queen of Black Magic (DVD) (n.d.). Retrieved from https://www.amazon.com/Queen-BlackMagic-Suzzanna/dp/B0017VG62W/ref=sr_1_1 ?ie $=$ UTF $8 \& q i d=1542082567 \&$ sr $=8$ $1 \&$ keywords=Queen+of+Black+Magic

Restored classic Tiga Dara set for cinema return (2016, June 23). The Jakarta Post. Retrieved from. http:// www.thejakartapost.com/life/2016/06/23/restored-classic-tiga-dara-set-for-cinema-return.html

Said, S. (1991). Shadows on the silver screen: A social history of Indonesian film. Jakarta: Lontar Foundation.

Schaefer, E. (1999). Bold! Daring! Shocking! True!: A history of exploitation films, 1919-1959. Durham \& London: Duke University Press.

Sekarjati, A. (2012a, April 27). Lewat djam malam di festival film Cannes 2012 [After Curfew at 2012 Cannes film festival]. Film Indonesia. Retrieved from http://filmindonesia.or.id/article/lewat-djam-malamdi-festival-film-cannes-2012.

Sekarjati, A. (2012b, May 14). Restorasi film Lewat Djam Malam. Film Indonesia. Retrieved from http:// filmindonesia.or.id/article/restorasi-film-lewat-djam-malam.

Sofyan, A.M, Katili, H., \& Gunawan S. (Producers), \& Djalul, T. (Director). (1981). Mistik (Punahnya Rahasia IImu Iblis Leak) [Mystics in Bali] [DVD]. Jakarta: Pan Asiatic Film.

Soraya, R (Producer) \& Djalil,T (Director) (1988). Lady Terminator [DVD]. Indonesia: Soraya Intercine Film. Telotte, J. (Ed.). (1991). The cult film experience, beyond all reason. Austin: University of Texas Press.

The Devil's Sword (n.d.). Retrieved from http://www.mondomacabrodvd.com/mod126.html

Tombs, P., \& Starke, A. (Producers), \& Tombs, P., \& Starke, A. (Directors). (2004). Fantasy Film from Indonesia. In Lady Terminator [DVD]. London: Boum Production.

Tombs, P., \& Starke, A. (Producers), \& Tombs, P. \& Starke, A. (Directors) (2007). Interview with Gope Samtani (DVD). The Warrior [DVD]. London: Boum Production.

The Warrior (2018). Retrieved from http://www.mondomacabrodvd.com/mod137.html

The Warrior (DVD) (n.d.). Retrieved from https://www.amazon.com/Warrior-Eva-Arnaz/dp/ B001EAWMME/ref=sr_1_1?ie=UTF8\&qid=1542082316\&sr=8-1\&keywords=The+Warrior+mondo + macabro

Virgins from Hell (DVD) (n.d.). Retrieved from https://www.amazon.com/Virgins-HellDVD-Enny-Beatrice/dp/B000CCD24C/ref=sr_1_1?ie=UTF8\&qid=1542081966\&sr=8$1 \&$ keywords=Virgins+from+Hell. 
Watson, P. (1997). There's no accounting for taste: Exploitation cinema and the limits of film theory. In D. Cartmell, et al. (Eds.), Trash aesthetics: Popular culture and its audience (pp. 66-87). London \& Sydney: Pluto Press.

Wenjie, Z. (2012) Merdeka! The Films of Usmar Ismail \& Garin Nugroho (2012). Singapore: Dominie Press Singapore and National Museum of Singapore.

Wiranegara, R.G., \& Abiyoga, B. (Producers), \& Mizwar, D. (Director). (2007). Nagabonar jadi dua [Nagabonar became two] [DVD]. Jakarta:DemiGisela Pictures.

\section{Endnotes}

1 The table is a modification of data made by Barker (2014) for the list of DVDs and from searches in Amazon.com for the dates of DVD releases. Please check ("Lady Terminator (DVD),'n.d.); ("Mystics in Bali (DVD),"n.d.), ("Dangerous Seductress (DVD),"n.d.), ("Virgins from Hell (DVD),"n.d.), ("The Warrior (DVD),"n.d.), (“Devil's Sword (DVD),"n.d.), (“Queen of Black Magic (DVD),' n.d.).

2 Please see: Gatra 8 May 2008, http://arsip.gatra.com/2008-05-18/artikel.php?id=114767 and Koran Tempo 15 May 2008. http://www.tempo.co/read/news/2008/05/15/071123133/Sajak-JenderalNagabonar.

3 The titles are Darah Muda (Young Blood), Begadang (Stay Overnight), Melodi Cinta (Melody of Love), Perjuangan dan Doa (Struggle and Prayer), Cinta Kembar (Twin Love), Cukong Bloon (Stupid Tycoon), Biang Kerok Beruntung (The Lucky Troublemaker), Sama Gilanya (Both of You are Crazy!), and Para Perintis Kemerdekaan (The Pioneer of Independence).

4 The other term is "self-conscious cultism" (Mathijs \& Sexton, 2011, p. 235), which refers to filmmakers labeling themselves as filmmakers of cult films, such as Tim Burton, Joe Dante, and Quentin Tarantino.

5 As underlined by Pete Tombs: "There is a small but niche audience for films that are different from the mainstream Hollywood product and this is where we try to market our movies, stressing their exotic, extreme or unusual content" (as cited in Imanjaya, 2009c, p. 144).

6 The titles are The Erotic Empire (2002), Argentinian Exploitation (2002), Fantasy Films from Indonesia (2002), The Nightmares of Coffin Joe (2002), Thrillers from Manila (2002), South Asian Cinema (2002), Mexican Horror Movies (2002), and Turkish Pop Cinema (2001). Each episode has a 25minute duration.

\section{Acknowledgement}

The author would like to express his sincere thanks and gratitude to his supervisors, Mark Jancovich and Rayna Denison, for their supervision and guidance during his PhD study.

EKKY IMANJAYA is faculty member at Film Program, Bina Nusantara University. He just finished his PhD study in Film Studies at School of Arts, Media, and American Studies, University of East Anglia (UK). $\mathrm{His} \mathrm{PhD}$ research is about cultural traffic of classic Indonesian exploitation cinema. The research was funded by DIKTI Scholarship, Higher Education Directorate, Ministry of Research, Technology, and Higher Education, Republic of Indonesia. (corresponding author: eimanjaya@binus.edu) 